\title{
Earthquake seismology in Greenland - improved data with multiple applications
}

\author{
Tine B. Larsen, Trine Dahl-Jensen, Peter Voss, Thomas Møller Jørgensen, Søren Gregersen \\ and Hans Peter Rasmussen
}

Earthquake seismology is a rapidly evolving field that has provided a wealth of new information about deep geological structures on a regional scale over the last decade as well as information about dynamic processes in the Earth. A major leap forward was the development of portable digital broad band (BB) seismographs around 1990. Without any changes in configuration, these are able to record the signals from large distant earthquakes, as well as the signals from weak local events. BB seismographs typically cover a frequency range from $0.0083 \mathrm{~Hz}$ to $50 \mathrm{~Hz}$, making them useful for studies ranging from the high frequency signals from explosions to the very low frequency oscillations following major earthquakes. The first seismological observatory in Greenland was established in 1907 in Qeqertarsuaq (GDH) and was in service for about five years (Hjelme 1996). Later, seismographs were established in Ivittut (1927) and Illoqqortoormiut (1928; SCO), and the network has been regularly upgraded and expanded ever since (Fig. 1). Prior to the development of BB seismographs, each station was equipped with a set of seismographs with different frequency sensitivities in an attempt to cover both distant and local earthquakes. Now just one small instrument is needed at each location.

The Geological Survey of Denmark and Greenland (GEUS) operates four permanent BB seismographs in Greenland (Fig. 1), two of them in collaboration with foreign institutions. In addition to the permanent network, there are currently 13 temporary BB seismographs active in Greenland, of which eight are operated by GEUS. Three of the temporary seismograph stations were established as part of the Danish Continental Shelf Project (Marcussen et al. 2004), and the remainder in connection with research projects. Three temporary seismographs were deployed during 2005 as part of a research project aiming to resolve very deep regional structures in North Greenland: the Citronen Fjord station (CFJ, Continental Shelf Project), and the stations in Kullorsuaq (KUL) and Daneborg (DBG).

\section{The seismological service in Greenland}

The study of earthquakes is international by nature. Large earthquakes can be recorded world wide, and a good coverage of high quality data is crucial for an accurate determination of an epicentre. Epicentral determination for large

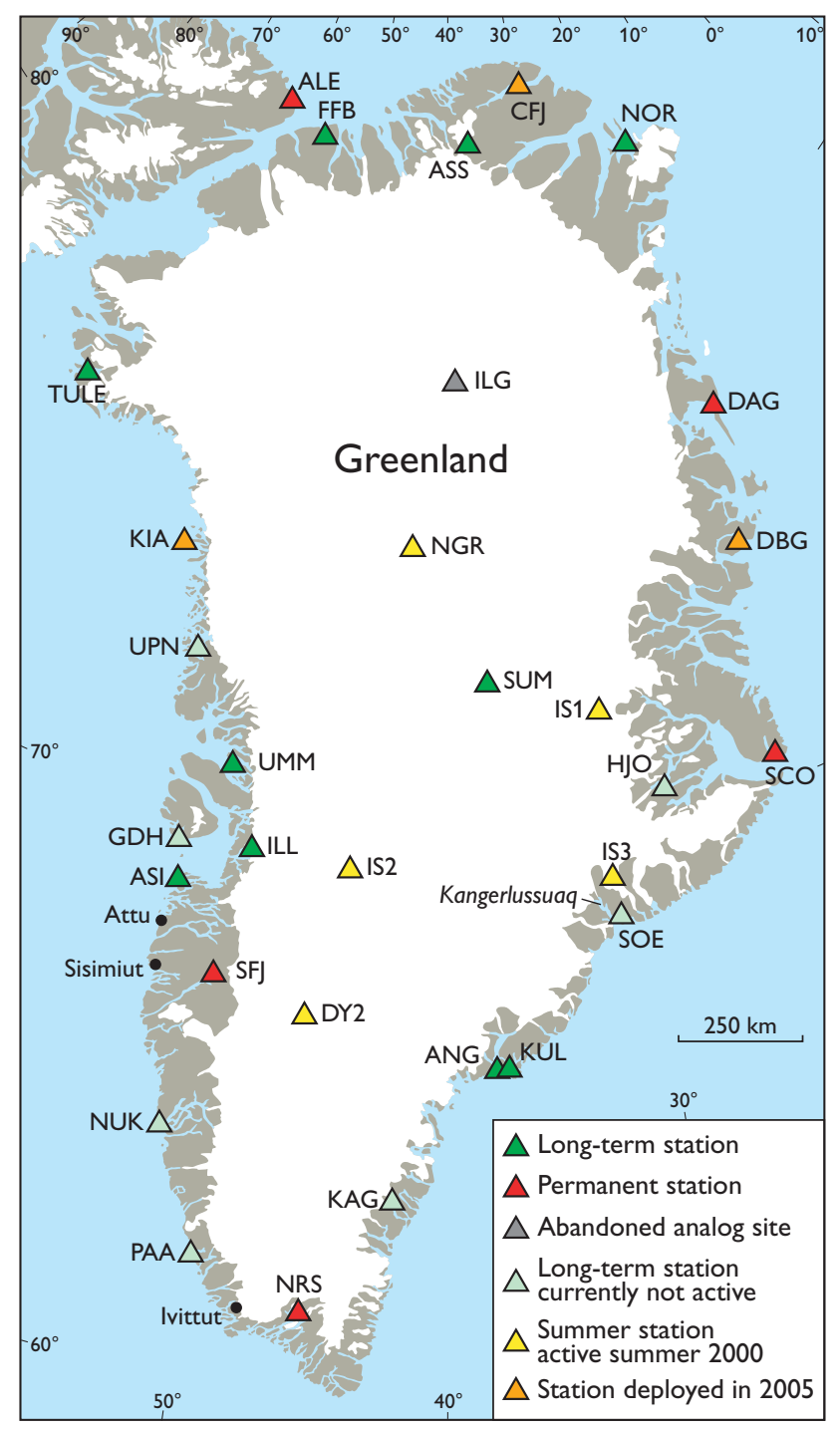

Fig. 1. Seismograph stations in Greenland.

earthquakes is carried out at international data centres through collaboration of seismic services in almost all countries of the world. The primary task for the seismology group at GEUS is to maintain the seismological service for Denmark and Greenland (see Gregersen et al. 2004). The seismological service runs the permanent network of seismographs, that collects high quality continuous data, analyses the data, and reports registered earthquake signals (phases) for local earthquakes as well as for regional and teleseismic events. The 
continuous digital waveform data are freely available directly from a GEUS server, as well as through international data centres. Due to Greenland's size and geographical location, data from Greenland are particularly important to the international seismological community. Currently, the Kangerlussuaq (SFJ) seismograph and the seismograph at the Summit ice camp (SUM) are the only two in Greenland with real-time data transmission. Data from other stations are available with varying time delay. The phase readings are reported to international data centres such as the United States Geological Survey (USGS) and the International Seismological Centre (ISC) through the weekly bulletin and the revised monthly bulletin. In 2005, GEUS reported a total of 3999 earthquake signals from the permanent seismograph network in Greenland, including many of the aftershocks that continued for several months after the Sumatra earthquake on 26 December, 2004, as well as the devastating 7.6 Richter Scale Kashmir earthquake on 8 October, 2005 (Fig. 2).

The seismograph in Kangerlussuaq was moved $300 \mathrm{~m}$ in February 2005 to a vault protected from local radar antenna disturbances. This was carried out in order to serve better the needs of the Comprehensive Test Ban Treaty Organisation (CTBTO). CTBTO financed the move, and provides in addition the real-time satellite transmission of the continuous data. The instrumentation was supplemented in 2005 with an extra BB seismograph. The CTBTO is an organisa-

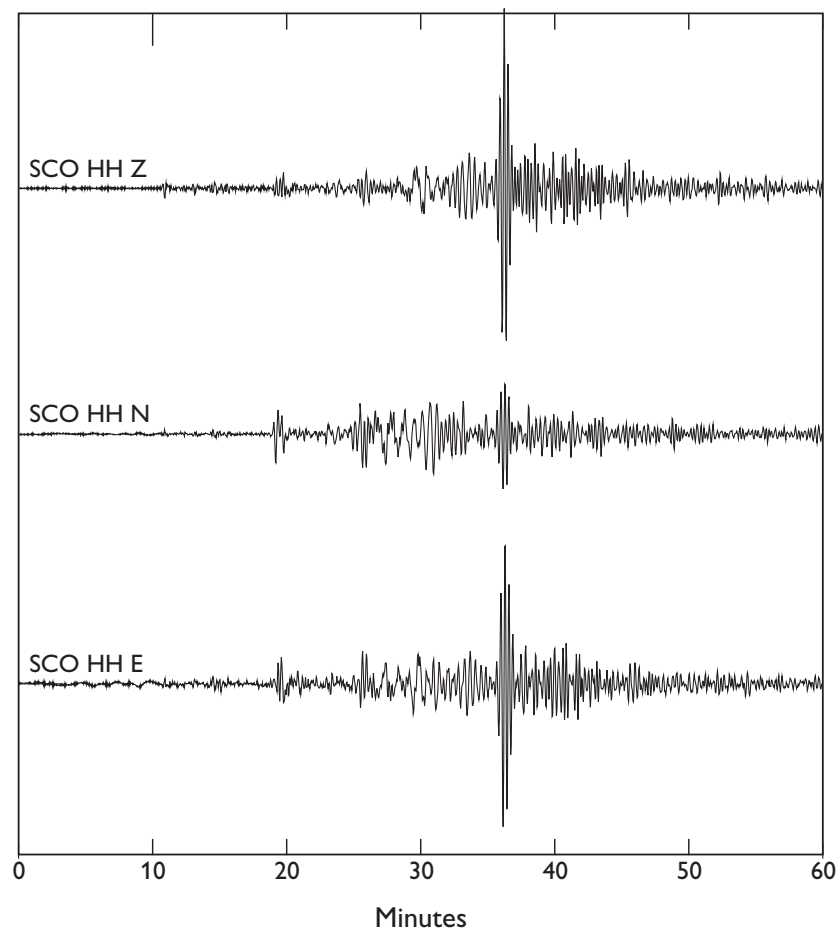

Fig. 2. Seismograms for the Richter scale 7.6 Kashmir earthquake on 8 October, 2005 recorded at Illoqqortoormiut. The top seismogram shows the vertical motion, the middle seismogram motion in the north-south direction, and the bottom seismogram motion in the east-west direction. tion under the United Nations, and its goal is to detect nuclear explosions of more than $5 \mathrm{~kg}$ fissionable material anywhere on Earth. An important tool for the organisation is seismological surveillance carried out by a primary and a secondary global network of designated secure seismograph stations. The Kangerlussuaq seismograph is part of the secondary network, and was officially certified by CTBTO on 24 November 2005. GEUS is Denmark's National Authority for the CTBTO.

Several minor earthquakes occurred in Greenland in 2005. GEUS received reports that earthquakes were felt in Qeqertarsuaq (GDH) on 30 March, in Sisimiut on 23 July, at Station Nord (NOR) on 30 August, and in Attu on 23 October. Tasiilaq (ANG) is normally the place in Greenland where most earthquakes are felt; however, no earthquakes were reported in 2005. Including the reports of felt earthquakes noted above, GEUS has so far registered 20 earthquakes in Greenland in 2005 (Fig. 3). This number may increase when the preliminary earthquake catalogue is quality controlled and revised, and data from the temporary seismographs are recovered and included.

\section{Studies on deep crustal and mantle structures}

Denmark ratified the United Nations Convention on the Law of the Sea (UNCLOS) in November 2004. After ratification of UNCLOS, a country has ten years to collect the appropriate information and submit a claim for an extended continental shelf beyond 200 nautical miles. One of the potential claim areas is the continental shelf north of Greenland (Marcussen et al. 2004). Three BB seismographs have been placed along the North Greenland coast (Fig. 1) with the aim of learning more about the thickness and structure of the crust of North Greenland through receiver function analysis. This method has previously been used at many sites in Greenland during the GLATIS (Greenland Lithosphere Analysed Teleseismically on the Ice Sheet) project, but all BB seismographs used in previous studies were located further south (Dahl-Jensen et al. 2003). The stations at Frankfield Bugt (FFB) and Aftenstjernesø (ASS) have been in operation since 2004, whereas the Citronen Fjord station (CFJ) started recording data in 2005. These stations record signals from distant (teleseismic) earthquakes that can be processed to obtain information about crustal structure, e.g. depth to Moho and even deeper structures. The data retrieved so far are of excellent quality. Normally it is necessary to record data for more than a year in order to obtain a reliable estimate for the depth to Moho, but for the Aftenstjernesø station a depth to Moho of $41 \mathrm{~km}$ and a $\mathrm{Vp} / \mathrm{Vs}$ of 1.71 was determined using just a few months of data. The relatively 
large depth to Moho at Aftenstjernesø indicates that the station is on the rim of the Precambrian shield area (Fig. 3), and data from other locations are therefore necessary to resolve the question of crustal thickness in the Franklinian Basin that extends along the North Greenland coastal region.

Surface waves from teleseismic earthquakes can provide information on deep geological structures between two seismographs recording the same earthquake. Provided that two seismographs are located on the same great circle as the epicentre, differences in the signal recorded on the two instruments will reflect the geology affecting the wave propagating between the two stations. A dense web of epicentres and station pairs will make it possible to construct a seismic velocity model from depths of about $60 \mathrm{~km}$ to about $300 \mathrm{~km}$. This kind of analysis was successfully carried out during the GLATIS project (Darbyshire et al. 2004). Similar studies were made previously by Gregersen $(1970,1982)$ for the crust, using various kinds of seismic waves. In addition to the studies of velocity structure in the mantle, measurements of amplitude attenuation have been carried out (Jørgensen 2005), resulting in preliminary maps of differences in the wave absorption properties of the deep structures.

In order to take full advantage of the seismographs along the north coast of Greenland and improve coverage inland north of $72^{\circ} \mathrm{N}$, it was necessary to deploy two extra seismographs, one in the settlement of Kullorsuaq (KUL), and another at Daneborg (DBG) that was previously used by the GLATIS project (Fig. 1). Both seismographs were installed in 2005 and will remain in operation until 2007. It is expected that a first-order model of the very deep velocity structures inland in North Greenland can be constructed within the framework of the project. In 2006 another deep-structure seismological project will deploy a short profile of five BB seismographs across the Safartoq kimberlite region south-east of Sisimiut. The aim of this project is to reveal the crustal thickness in the area. The Safartoq project will be initiated as a pilot study of the area in order to facilitate a proposal for a large-scale deep structure study with international partners. A larger array of instruments is necessary for studies of the deep lithospheric structures.

\section{Glacial earthquakes}

Glacial earthquakes are a peculiar type of seismological event primarily located in Greenland. They were first described by Ekström et al. (2003). The signals are dispersive, lack the characteristic P- and S- waves known from ordinary earthquakes and all signals appear to have their source beneath large glaciers. The focal mechanisms that can be calculated for the earthquakes are consistent with a large mass of ice moving abruptly downhill over an elastic medium (landslide model).
In 2005 Geocenter Copenhagen funded a joint research project on glacial earthquakes involving GEUS and the Institute of Geography, University of Copenhagen. Through the GLATIS project GEUS possesses a unique seismological data set for Greenland, previously used only for structural studies. When the majority of BB seismographs in Greenland were installed, the existence of glacial earthquakes had not been recognised. However, after the start of the glacial earthquake project in 2005, it has become clear that the BB seismological data from Greenland are a unique data set for the study of glacial earthquakes.

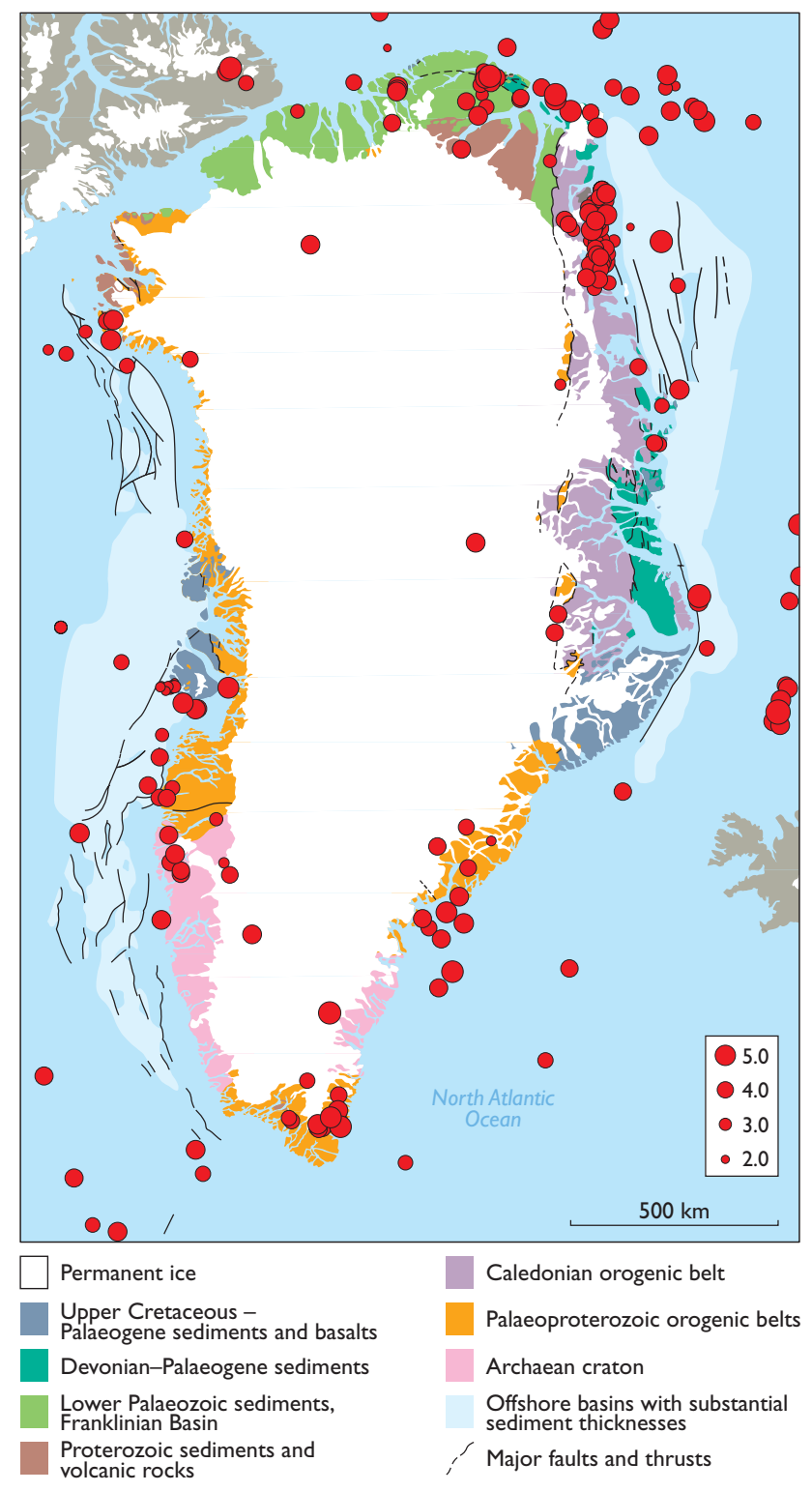

Fig. 3. Map of earthquake locations in and around Greenland for 19702005. Only earthquakes with a magnitude of 2.0 or more on the Richter Scale are shown. The map is compiled from the GEUS earthquake database, supplemented with epicentre locations from the Geological Survey of Canada, the United States Geological Survey and NORSAR in Norway. 
A

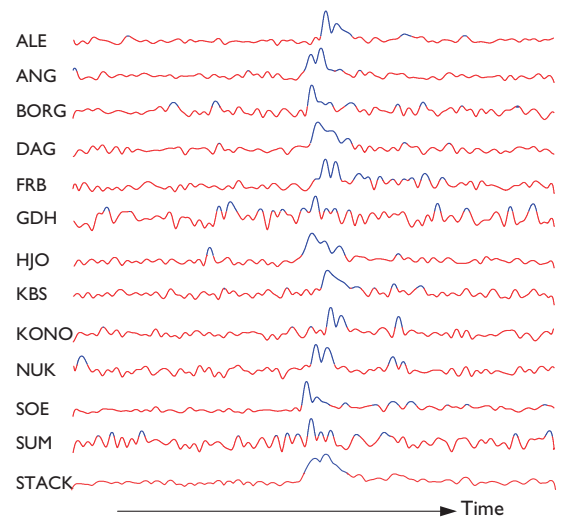

B

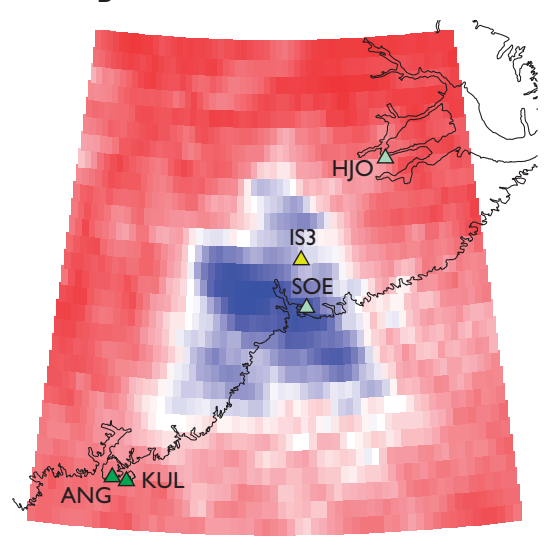

Fig. 4. A: Seismogram envelopes for a glacial earthquake, that occurred on 20 October,

2000. Signal from the earthquake is shown in blue. The bottom seismogram is a stack of the twelve seismograms, relative to a chosen test epicentre. When the test epicentre is close to the true epicentre, stacking will produce a strong signal. For location of Greenland stations see Fig. 1. ALE: Alert, Arctic Canada. BORG: Borganes, Iceland. FRB: Frobisher Bay, Arctic Canada. KBS: Kingsbay, Svalbard; KONO: Kongsberg, Norway. B: Correlation for the signal in the stack, with the best correlation in blue. Many test epicentres are modelled before the true epicentre can be determined, in this case centred in Kangerlussuaq in East Greenland (see Fig. 1).
Glacial earthquakes have not previously been studied extensively using a local data set (Fig. 4). One purpose of the project is to significantly improve the location accuracy for the earthquakes, and to improve the detection threshold by an order of magnitude from 4.7 on the Richter Scale to 3.7. Detecting smaller earthquakes opens the possibility of revealing unknown ice streams within the Greenland ice sheet.

The occurrence of glacial earthquakes shows strong seasonal variation, with most earthquakes occurring during summer. This implies that the glacial earthquakes could contribute information as to how variations in climate parameters affect ice sheet dynamics. GPS fieldwork is planned for summer 2006, when glacial earthquakes will be recorded simultaneously on both seismographs and differential GPS. The objective of the project is to shed light on the mechanisms controlling the glacial earthquakes, with the possibility that glacial earthquakes can be used as a surveillance tool to study Greenland ice sheet dynamics.

\section{Acknowledgements}

GeoForschungsZentrum-Potsdam (GFZ), Germany provides instrumentation and technical support to the seismograph in Danmarkshavn, and together with the Incorporated Research Institutions for Seismology (IRIS), USA to the seismograph in Kangerlussuaq. The Bureau of Minerals and Petroleum, Government of Greenland, provided financial support to several of the projects described in this paper. Geocenter Copenhagen provides financial support for the project on glacial earthquakes.

\section{References}

Dahl-Jensen, T., Larsen, T.B., Woelbern, I., Bach, T., Hanka, W., Kind, R., Gregersen, S., Mosegaard, K., Voss, P. \& Gudmundsson, O. 2003: Depth to Moho in Greenland: Receiver-function analysis suggests two Proterozoic blocks in Greenland. Earth and Planetary Science Letters 205, 379-393.

Darbyshire, F.A., Larsen, T.B., Mosegaard, K., Dahl-Jensen, T., Gudmundsson, O., Bach, T., Gregersen, S., Pedersen, H.A. \& Hanka, W. 2004: A first detailed look at the Greenland lithosphere and upper mantle, using Rayleigh wave tomography. Geophysical Journal International 158, 267-287.

Ekström, G., Nettles, M. \& Abers, G.A. 2003: Glacial earthquakes, Science 302, 622-624.

Gregersen, S. 1970: Surface wave dispersion and crust structure in Greenland. Geophysical Journal of the Royal Astronomical Society 22, 22-39.

Gregersen, S. 1982: Seismicity and observations of Lg wave attenuation in Greenland. Tectonophysics 89, 77-93.

Gregersen, S., Glendrup, M., Larsen, T.B., Voss, P. \& Rasmussen, H.P. 2004: Seismology: neotectonics and structure of the Baltic Shield. Bulletin of the Geological Survey of Denmark and Greenland 7, 25-28.

Hjelme, J. 1996: History of seismological stations in Denmark and Greenland. In: Wahlström, R. (ed.) Seismograph recording in Sweden, Norway - with arctic regions, Denmark - with Greenland, and Finland. Proceedings from the Uppsala Wiechert Jubilee Seminar, 49-57. Uppsala: Seismological Department, Uppsala University, Sweden.

Jørgensen, T.M., 2005: Attenuation of Rayleigh waves in Greenland, 78 pp. Unpublished M.Sc. thesis, University of Copenhagen, Denmark.

Marcussen, C., Christensen, F.G., Dahl-Jensen, T., Heinesen, M., Lomholt, S., Møller, J.J. \& Sørensen, K 2004: Exploring for extended continental shelf claims off Greenland and the Faroe Islands. Bulletin of the Geological Survey of Denmark and Greenland 4, 61-64.

\footnotetext{
Authors' address

Geological Survey of Denmark and Greenland (GEUS), Øster Voldgade 10, DK-1350 Copenhagen K, Denmark. E-mail: tbl@geus.dk
} 